\title{
MENGUKUR KINERJA OPERASIONAL BMT PADA TAHUN 2010 DITINJAU DARI SEGI EFISIENSI DENGAN DATA ENVELOPMENT ANALYSIS (DEA) (Studi Kasus BMT Di Kota Semarang)
}

\author{
Heny Yuningrum ${ }^{1}$
}

\begin{abstract}
Abstrak
The development of Islamic banking in Semarang city was rapidly since 1997 until 2012. It is thanks to the Government support in the terms of determine Islamic banking. The Support is now more easy for movement of Islamic financial institutions. the author chose the year 2010 of this research because 2010 have been reported complete leadership of the BMT. The issue of this research is how the operational of activities BMT in Semarang city has reached the level of operational efficiency in 2010 and how the forward prospects in Semarang city for competition of BMT with the another syariah financial.The population of this research are 72 BMt and the sampling of this research are 12 BMT. The population and the sample was listed by PUSKOPSYAH. The analyze of this research using WDEA which is expected to be answer the problems occurred in the BMT.

The result of this Research are 3 BMT has efficiency of 55\% until 90\%. There are BMT Mitra Hasanah (61,51), BMT Pasadena (62,41\%) and BMT Anda (71,18\%). The capital and the operational expenses of three BMT must to increase until hit a target was expected. The average of That BMT only 30\% from the target. And the BMt have low efficiency (less than 55\%) i.e. BMT Hudatama (29,22\%, BMT Fosilatama (33,28\%), BMT Tumoto Bondo (47,81\%). While a third of this BMT have low efficiency from variable input i.e. capital and operational expenses and savings. There are need to upgraded from 50\% until 70\%. The deficiency occurs in the BMT are the proportion of unbalanced input i.e. capital and operational expenses, the number of entries maintained does not match your target market. To achieve those targets each BMT must add capital, operating expenses and savings.To answering the problemof inefficient are: the value of output that should be improved by reducing the input, if the input and output was increased, so the level to the increase fof output must be greater than the rate of increase for input, or the both of output and input was decline because the derived output should be lower than input.
\end{abstract}

Keyword : efficiency, DEA analyze

\section{A. PENDAHULUAN}

Perkembangan industri keuangan syariah di Indonesia mengalami kemajuan pesat. Perkembangan industri keuangan syariah diawali dengan terbitnya Undang-Undang

\footnotetext{
${ }^{1}$ Dosen Fakultas Syariah IAIN Walisongo Semarang
} 
No 10 tahun 1998 tentang perubahan Undang-Undang No 7 tahun $1992^{2}$, dan terbitnya Undang-Undang No 23 tahun 1999 tentang Bank Indonesia. Perkembangan selanjutnya yaitu keluarnya fatwa tentang haramnya bunga bank yang dikeluarkan oleh MUI pada tahun 2003, keluarnya fatwa ini memberikan kontribusi terhadap pertumbuhan industri perbankan syariah. Perkembangan selanjutnya adalah dengan terbitnya peraturan perundang-undangan, yaitu Undang-Undang No 21 tahun 2008 yang mengatur tentang operasional perbankan syariah di Indonesia dan diperbaharui dengan terbitnya Peraturan Bank Indonesia (PBI) No 11/3/PBI/2009 yang memuat tentang prosedur dan aturan dalam mendirikan kantor cabang, membuat perkembangan jumlah kantor layanan bank syariah bertambah dengan pesat.. Dan diberlakukannya Undang-Undang No.21 Tahun 2008 tersebut yang terbit tanggal 16 Juli 2008, maka pengembangan industri perbankan syariah nasional semakin memiliki landasan hukum yang memadai dan akan mendorong pertumbuhannya secara lebih cepat lagi. Dengan progres perkembangannya yang impresif, yang mencapai rata-rata pertumbuhan aset lebih dari $65 \%$ pertahun dalam lima tahun terakhir, maka diharapkan peran industri perbankan syariah dalam mendukung perekonomian nasional akan semakin signifikan. Hal ini dapat dilihat dari data statistik perbankan syariah Bank Indonesia (Januari 2010), jumlah unit kantor cabang syariah di Jawa Tengah mengalami peningkatan yang cukup pesat, yaitu mencapai 815 kantor cabang bank umum syariah dan 268 kantor cabang bank konvensional yang membuka unit usaha syariah (www.bi.go.id)

Implikasi positif dari kebijakan pemerintah diatas adalah banyak berdirinya lembaga-lembaga keuangan syariah. Dalam perkembangannya sekarang ini, ada dua jenis lembaga keuangan syariah yaitu lembaga keuangan syariah yang berupa bank dan non bank. Lembaga keuangan syariah yang berupa bank terdiri dari Bank Umum Syariah (BUS) dan Unit Usaha Syariah (UUS) sedangkan lembaga keuangan syariah non bank antara lain berupa Asuransi Syariah (AS), Baitul Maal Wa Tamwill (BMT), Unit Simpan Pinjam Syariah (USPS). Fungsi dasar dari lembaga keuangan syariah yaitu sebagai lembaga perantara atau intermediasi yang menghubungkan antara pihak-pihak yang kelebihan dana dengan pihak-pihak yang kekurangan dana.

Perkembangan BMT di Jawa Tengah sungguh sangat signifikan. Menurut PINBUK Jawa Tengah jumlah BMT tahun 2003 adalah 262 unit dan data tahun 2011 sebanyak 513 unit atau mengalami kenaikan sebesar 95,8 \%. Kenaikan jumlah BMT tersebut ternyata tidak diimbangi dengan eksistensi operasional BMT. Menurut penelitian dari Kholim ${ }^{3}$ bahwa ketidak eksistensi BMT dapat dilihat dari beberapa aspek yaitu :

1. Prinsip - prinsip syariah belum sepenuhnya dipahami sumber daya manusianya dalam hal ini adalah personalia / pegawai dalam BMT.

2. Sampai sekarang masih kesulitan mencari figur yang tepat untuk menduduki Dewan Pengawas Syari'ah. ${ }^{4}$

3. Sistem perbakan syariah dan proses pengelolaan yang dianut BMT belum banyak dipelajari oleh masyarakat .

4. BMT dan lembaga keuangan syariah belum banyak dikenal masyarakat Islam sendiri.

2 UU No 10 tahun 1998 tentang perubahan Undang-Undang No 7 tahun 1992,yang mengatur tentang peraturan yang membolehkan setiap bank konvensional membuka sistem pelayanan syariah di cabangnya (dual banking system)

3 Muhammad Kholim, 2004, Eksistensi Baitul Maal Wattamil dan Permasalahannya dalam Operasionalisasinya (Studi di Propinsi Jawa Tengah), hal : 122 - 126

4 Alasan belum menemukan figure yang tepat antara lain : sebagian besar ulama kita masih bercorak tradisional konserfatif yaitu sulit menerima perubahan, serta tidak memiliki wawasan mengenai perbankan. 
5. Dibutuhkan proses panjang mengenalkan kepada masyarakat mengenai system bagi hasil.

6. Implementasi prinsip-prinsip syariah dalam operasional BMT hingga sekarang masih dihadapkan pada kendala teknis seperti konsep pengerahan, dan penyaluran dana yang perlu disempurnakan.

7. Masih banyak pengelola BMT yang berorientasi pada profit oriented.

8. Kedudukan BMT di mata tata hokum perbankan masih sangat lemah.

Ketidak eksistensian tersebut sangatlah perlu dikaji apakah memang kinerja BMT yang terjadi sudah maksimal atau belum untuk mengurangi beberapa kelemahan yang dimiliki BMT itu sendiri.

\section{B. PERUMUSAN MASALAH}

Bank syariah sebagai salah satu jenis lembaga keuangan syariah pada kenyataannya masih belum mampu menjangkau Usaha Mikro Kecil dan Menengah (UMKM). Padahal lapisan inilah penyedia lapangan kerja terbesar di Indonesia. Kenyataan di lapangan membuktikan bahwa layanan pembiaayaan dengan menggunakan pendekatan perbankan sulit dilakukan dan tidak menjangkau UMKM dikarenakan adanya faktor yang membatasi hubungan UMKM dengan perbankan, yaitu masalah agunan dan formalitas (Suhendi, 2004). Namun demikian saat ini telah ada lembaga keuangan syariah yang berpihak pada pengusaha mikro yaitu Baitul Mal Wa Tamwil (BMT).

Menurut Ridwan (2004), BMT merupakan sebuah lembaga yang tidak saja berorientasi bisnis tetapi juga sosial, dan juga lembaga yang tidak melakukan pemusatan kekayaan pada sebagian kecil orang tetapi lembaga yang kekayaannya terdistribusi secara merata dan adil. BMT juga merupakan lembaga keuangan syariah yang jumlahnya paling banyak dibandingkan lembaga-lembaga keuangan syariah lainnya. Menurut Aziz (2004), pada tahun 2001 jumlah BMT di Indonesia yang terdaftar sebanyak 2938 sedangkan Pusat Inkubasi Bisnis dan Usaha Kecil (PINBUK) menargetkan terdapat 10.000 BMT di akhir tahun 2010. Namun yang terjadi adalah jumlah BMT pada tahun 2010 terdapat hanya 3872 BMT. ${ }^{5}$ Sehingga target yang diharapkan PINBUK tidak terealisasikan.

Perkembangan BMT di Jawa tengah menurut data dari PINBUK berjumlah 526 unit pada tahun 2001, kemudian pada tahun 2002 meningkat menjadi 537 unit dan pada tahun 2003 menurun menjadi 526. Sedangkan Perkembangan BMT di Kota Semarang berjumlah 15 unit pada tahun 2001kemudian turun menjadi 10 unit pada tahun 2002, dan pada tahun 2003 meningkat menjadi 15 unit BMT. Di Kota Semarang hal ini perlu ada pengkajian lebih lanjut untuk menjawab ketidak tercapaian target tersebut. Penelitian ini dilakukan untuk menjawab permasalahan yang terjadi tersebut.

Kenaikan jumlah BMT yang sangat lambat dilatar belakangi adanya beberapa faktor permasalahan yang terjadi di intern BMT maupun di luar BMT termasuk faktor ketidak eksistensian BMT (tercantum dalam Pendahuluan penelitian ini).

Perlu diketahui bahwa banyak lembaga keuangan mikro syariah yang tersebar di Indonesia ternyata masih belum memberikan sinyal positif, termasuk Baitul Mal Wa Tamwil (BMT). Sebagai lembaga keuangan mikro yang mempunyai keberpihakan terhadap masyarakat ekonomi lemah, banyak tantangan dan permasalahan yang timbul dan dihadapi dalam perkembangan BMT, baik yang bersifat internal maupun eksternal. Menurut Sadrah dkk (2004) tidak jarang bahwa pendirian BMT kurang diimbangi dengan pengetahuan, pengalaman, dan keterampilan yang professional mengenai manajemen pengelolaan, servis, maupun sumber daya manusia (SDM) Oleh

${ }^{5}$ Pinbuk Inisiasi Kelahiran BMT tahun 2010 sebanyak 3.872 Unit, jpmi.or.id, di posting pada tanggal 5 Maret 2012. 
karena itu banyak diantara BMT-BMT tersebut yang muncul kemudian mati dalam usia pendek atau tumbuh tetapi berdiri ditempat tidak bisa melangkah, dan sedikit yang dapat berjalan itupun dengan tertatih-tatih. Munculnya begitu banyak BMT di Indonesia tidak didukung oleh factor-faktor yang dapat mendukung suatu BMT untuk dapat terus berkembang dan berjalan dengan baik. Fakta di lapangan menunjukkan banyak BMT yang tenggelam dan bubar disebabkan berbagai hal, antara lain karena manajemen yang kurang profesional, pengelola yang tidak amanah memunculkan ketidakpercayaan masyarakat sehingga memicu penarikan dana secara besar-besaran dan kesulitan modal. ${ }^{6}$

Selain kelemahan internal BMT yang telah disebut diatas, juga dihadapkan pada tantangan yang lebih berat yaitu BMT tidak dapat lagi mengandalkan modal kepercayaannya pada sentimen masyarakat tentang isu-isu syariah, seperti keharaman riba dan sistem bunga serta menjalankan sistem ekonomi berdasarkan syariah Islam (Sadrah dkk, 2004). Apalagi, Bank Syariah dan BPRS-BPRS dengan fasilitas dan permodalannya yang kuat semakin mempersempit ruang gerak BMT-BMT. Oleh karena itu mau tidak mau BMT harus meningkatkan efisiensi usahanya agar mampu bersaing dan bertahan hidup. Efisiensi merupakan perbandingan antara keluaran (output) dengan masukan (input) (Huri dan Susilowati, 2004). Kemampuan menghasilkan output yang maksimal dengan input yang ada merupakan ukuran kinerja yang diharapkan. Pada saat pengukuran efisiensi dilakukan, lembaga keuangan dihadapkan pada kondisi bagaimana mendapatkan tingkat output yang optimal dengan tingkat input yang ada atau dengan cara mendapatkan tingkat input yang minimum dengan tingkat output tertentu. Dengan menganalisa alokasi input dan output, dapat dianalisa lebih jauh untuk melihat ketidakefisienan.

Sehingga perumusan masalah dalam penelitian ini adalah seberapa efisien kinerja BMT di kota Semarang demi menghadapi isu-isu perbankan syari'ah sekarang ini dan hal itu berkaitan dengan bagaimana prospeknya di masa depan demi menghadapi persaingan global lembaga keuangan syari'ah yang lain. Atau pertanyaan dalam penelitian ini adalah :

1. Apakah kegiatan operasional BMT di Kota Semarang telah mencapai tingkat operasional yang efisien pada tahun 2010.

2. Bagaimana prospek ke depan BMT di Kota Semarang dalam menghadapi persaingan dengan lembaga keuangan syari'ah yang lain.

\section{TUJUAN DAN MANFAAT PENELITIAN}

Tujuan penelitian adalah :

a. Mengetahui kegiatan operasional BMT di Kota Semarang apakah telah mencapai tingkat operasional yang efisien belum pada tahun 2011.

b. Mengetahui prospek ke depan BMT di Kota Semarang dalam menghadapi persaingan dengan lembaga keuangan syari'ah yang lain.

Adapun manfaat penelitian adalah sebagai berikut:

a. Pihak BMT dan Lembaga Keuangan Syari'ah

Secara empiris penelitian ini dapat digunakan sebagai pertimbangan bagi masingmasing BMT di Kota Semarang dalam memajukan kegiatan operasionalnya. Serta dapat menjadi pertimbangan dalam menghadapi persaingan global lembaga keuangan syari'ah.

\footnotetext{
6 Santoso, 2003, hal : 60
} 


\section{b. Pembuat kebiijakan}

Penelitian ini diharapkan dapat menjadi masukan kepada berbagai pihak pembuat kebijakan perbankan syari'ah.

c. Pihak lain

Kontribusi teoritis bagi para mahasiswa atau peneliti lainnya sebagai pertimbangan penelitian-penelitian sejenis di sektor lainnya. Serta dapat memberikan referensi bagi kalangan akademisi untuk keperluan studi dan penelitian selanjutnya mengenai BMT.

\section{TINJAUAN PUSTAKA}

Kajian pustaka dalam penelitian ini berisi mengenai hasil penelitian penelitian dari para peneliti terdahulu. Tujuan dicantumkannya hasil penelitian terdahulu adalah sebagai acuan dasar penelitian ini dan sebagai pembanding perbedaan dasar penelitian ini dan hasil penelitian terdahulu.

a. Irawan, et.al (2006) dalam Sunarto (2010) yang melakukan penelitian mengenai kinerja rumah sakit umum di Jawa Timur. Efisiensi dan produktifitas sebuah rumah sakit selama ini diukur atas dasar pencapaian beberapa indikator seperti tingka $t$ dari pencapaian BOR ( Bed Occupancy Ratio), BTO ( Bed Turn Over), ALOS ( Average Length of Stay ), Penelitian dilakukan terhadap 42 rumah sakit umum pemerintah/daerah ya ng tersebar di Wilayah Propinsi Jawa Timur. Hasil penelitian menunjukkan nilai efisiensi teknis merentang dari 58,1\% hingga $100 \%$ pada tahun 2003 dengan 4 buah rumah sakit berada pada kondisi inefisien sementara nilai ef isiensi teknis pada 2004 merentang dari 59,6 \% hingga $100 \%$ dengan adanya tambahan rumah sakit yang turut mengalami penurunan tingkat efisiensi.

b. Vicky dan Niky ${ }^{7}$ dalam penelitiannya mengenai Pengukuran Kinerja Bank Komersial Dengan Pendekatan Efisiensi: Studi Terhadap Perbankan Go-Publik Di Indonesia. Menggunakan variable efisiensi yang diukur dengan rasio keuangan yaitu: rasio efisiensi dan rasio rentabilitas. Penelitian Vicky mengkombinasi analisis rasio dan Data Envelopment Analisys (DEA) sebagai teknik nonparametric untuk mengukur efisiensi perbankan di Indonesia. Dalam tulisan Vicky kinerja sebagai acuan efisiensi diukur sebagai acuan vector output yang diukur menggunakan 6 rasio perbankan tanpa input. Dan tulisannya tidak menggunakan rasio CAMELS sebagai alat pengukuran kinerja. Hal itu disebabkan karena CAMELS menilai kinerja perbankan dengan pendekatan tingkat kesehatan bank, sementara tulisan Vicky menggunakan pendekatan efisiensi DEA sebagai ukuran kinerja lembaga perbankan. Dihasilkan bahwa dari 51 observasi tidak menemukan satupun bank yang konsisten beroperaasi selama 3 tahun periode penelitian. Hasil penelitian menunjukkan bahwa hanya terdapat sebagian kecil bank komersial di Indonesia yang mampu berkinerja baik dan dapat digolongkan ke dalam bank yang relatif efisien.

c. Penelitian yang dilakukan oleh Rifki Ali Akbar $(2010)^{8}$ tentang Analisis Efisiensi Baitul Mal Wa Tamwil Dengan Menggunakan Data Envelopment Analysis (DEA) untuk Studi Kasus ada BMT Bina Ummat Sejahtera Di Jawa Tengah Pada Tahun 2009. Rifki menggunakan pendekatan intermediasi sebagai bentuk proses transformasi input menjadi output pada pendekatan ini, terkait dengan fungsi BMT sebagai financial intermediation dimana berbagai input yang dimiliki seperti biaya operasional, simpanan, jumlah tenaga kerja, modal, biaya bunga, aktiva tetap

\footnotetext{
${ }^{7}$ Vicky Rahma Putrid dan Niky Lucviaarman, 2008, JAAI, Volume 12 No 1, hal: 37-52

${ }^{8}$ Rifki Ali Akbar, 2010, penelitian yang tidak dipublikasikan, Fakultas Ekonomi Universitas

Diponegoro.
} 
dan sebagainya akan diubah menjadi output seperti dalambentuk pembiayaan, aktiva lancar, jumlah nasabah, pendapatan operasional lain, kas, investasi, dan lain sebagainya (Muharram dan Purvitasari, 2007). Penelitian Rifki menggunakan dua variabel input yaitu simpanan dan biaya operasional serta tiga variabel output yaitu pembiayaan, pendapatan operasional lain dan kas. Hasil penelitian disimpulkan bahwa Perhitungan skor efisiensi seluruh kantor cabang BMT BUS pada tahun 2009 menunjukkan terdapat 5 kantor cabang yang efisien secara relatif terhadap seluruh kantor cabang yang lainnya. Kelima kantor cabang tersebut adalah kantor cabang Blora, kantor cabang Purwodadi, kantor cabang Tawangharjo, kantor cabang Nambuhan dan kantor cabang Kendal. Sedangkan 26 kantor cabang yang lainnya mengalami inefisiensi. 4. Berdasarkan nilai efisiensi relatif dengan metode Data Envelopment Analysis (DEA) yang menggunakan asumsi variabel return to scale (VRS) dengan menggunakan model orientasi maksimalisasi output menghasilkan referensi kantor cabang yang efisien untuk dijadikan acuan bagi kantor cabang yang inefisien. Kantor cabang yang dapat dijadikan referensi adalah kantor cabang Blora, kantor cabang Purwodadi, kantor cabang Tawangharjo, kantor cabang Nambuhan dan kantor cabang Kendal.

Hasil penelitian mengenai efisiensi perbankan ini dijadikan acuan dalam penelitian ini karena pada dasarnya fungsi dari Bank sama dengan fungsi dari BMT yaitu sebagai lembaga intermediasi. Selain itu penelitian mengenai efisiensi BMT masih jarang dilakukan sehingga penelitian ini mengacu pada penelitian efisiensi perbankan. Dengan adanya research gap ini maka perlu diadakan penelitian lebih lanjut mengenai efisiensi.

Pengukuran kinerja lembaga keuangan dapat dilakukan melalui efisiensi yang dicapai oleh Lembaga keuangan pada suatu periode waktu tertentu. Pada penelitian ini menggunakan metode Data Envelopment Analysis (DEA), karena menurut Purwantoro (2004), DEA mempunyai beberapa Keunggulan diantaranya:

1. Dapat menangani banyak input dan output.

2. Tidak membutuhkan asumsi hubungan antar variabel input dan output.

3. UKE yang dibandingkan secara langsung dengan UKE yang sejenis.

4. Input dan Output dapat memiliki satuan pengukuran yang berbeda tanpa perlu melakukan perubahan satuan dari kedua variabel tersebut.

\section{LANDASAN TEORI}

Konsep efisiensi di awali dari konsep teori ekonomi mikro dan makro yaitu teori prodisen dan konsumen. Teori produsen mengatakan bahwa produsen cenderung memaksimalkan keuntungan dan meminimalkan biaya. Sedangkan teori konsumen cenderung memaksimalkan utilitas atau tingkat kepuasan. Dalam teori produsen dikenal dengan garis frontier yaitu garis yang mencerminkan tingkat input yang digunakan untuk menghasilkan output.

Suatu perusahaan dikatakan efisien apabila:

1. Menggunakan jumlah input yang lebih sedikit bila dibandingkan dengan jumlah unit input yang digunakan oleh perusahaan lain dengan menghasilkan output yang sama.

2. Menggunakan jumlah unit input yang sama dapat menghasilkan jumlah output yang lebih besar. ${ }^{9}$

9 Syafroedin dalam Muharram dan Purvitasari, 2007. "Analisis Perbandingan Efisiensi Bank Syariah dengan Metode Data Envelopment Analysis (periode tahun 2005), Jurnal Ekonomi dan Bisnis Islam, Vol.2, No.3 
Ditinjau dari Teori Ekonomi, ada dua pengertian efisiensi yaitu efisiensi teknik dan efisiensi ekonomi (Ghafur, 2007) ${ }^{10}$. Efisiensi ekonomi mempunyai sudut pandang makro yang mempunyai jangkauan lebih luas dibandingkan dengan efisiensi teknik yang bersudut pandang mikro. Pengukuran efisiensi teknik cenderung terbatas pada hubungan teknis dan operasional proses konversi input menjadi output. Akibatnya usaha untuk meningkatkan efisiensi teknis hanya memerlukan kebijakan mikro yang bersifat internal, yaitu dengan pengendalian dan alokasi sumber daya yang optimal

Terdapat 3 (tiga) kondisi keadaan Return To Scale ini, yaitu :

a. Jika $\lambda=1$ maka derajat perubahan keluaran sebagai hasil dari perubahan masukan disebut derajat perolehan tetap (constant returns to scale). Terjadi jika kenaikan output proporsional terhadap kenaikan input.

b. Jika $\lambda>1$ maka derajat perubahan keluaran sebagai hasil dari perubahan masukan disebut derajat perolehan menaik (increasing returns to scale). Kondisi yang terjadi jika kenaikan output > kenaikan input. Increasing Returns to Scale dapat terjadi karena dengan meningkatnya skala operasi, terjadi :

- Pembagian tugas yg lebih baik

- Spesialisasi tugas dan fungsi

- Penggunaan mesin-mesin khusus yg lebih produktif

c. Jika $\lambda<1$ maka derajat perubahan keluaran sebagai hasil dari perubahan masukan disebut derajat perolehan menaik (decreasing returns to scale). Kondisi ini terjadi jika kenaikan output < kenaikan input. Decreasing Returns to Scale dapat terjadi karena meningkatnya skala operasi organisasi namun terjadi kesulitan dalam mengkoordinasikan berbagai aktivitas dengan baik dan efektif Return to scale berguna dalam membantu pihak manajemen untuk memberikan informasi yang paling baik guna pembuatan keputusan manajerial dengan data yang akurat dan tepat.

Pembiayaan atau financing adalah pendanaan yang diberikan oleh suatu pihak kepada pihak lain untuk mendukung investasi yang telah direncanakan, baik dilakukan sendiri maupun lembaga. Dengan kata lain pembiayaan adalah pendanaan yang dikeluarkan untuk mendukung investasi yang telah direncanakan.

Secara umum tujuan pembiayaan adalah: ${ }^{11}$

a. Memaksimalkan laba

b. Meminimalkan resiko

c. Pendayagunaan ekonomi

d. Penyaluran kelebihan dana

Di dalam Ridwan (2004, hal : 26) ${ }^{12}$, pengertian pembiayaan berdasarkan Undangundang no. 7 tahun 1992 adalah penyediaan uang atau tagihan yang dapat dipersamakan dengan itu berdasarkan tujuan atau kesepakatan pinjam meminjam antara bank dengan pihak lain yang mewajibkan pihak peminjam untuk melunasi hutangnya setelah jangka waktu tertentu ditambah dengan sejumlah bunga, imbalan atau bagi hasil.

${ }^{10}$ Ghafur, M. 2007. Potret Perbankan Syariah Indonesia Terkini. Yogyakarta: Biruni Press.

${ }^{11}$ Muhammad, manajemen Bank Syari'ah, Yogjakarta, UPP AMP YKPN, 2002, hal: 260

${ }^{12}$ Ridwan, Muhammad, manajemen Baitul Maal Wa Tamwil (BMT), UII Press Yogjakarta, 
Permodalan yang dihimpun oleh lembaga keuangan pada dasarnya digunakan untuk kegiatan usaha. Permodalan tersebut diperoleh dari: ${ }^{13}$

1. Simpanan berupa Tabungan atau yang dipersamakan dengan itu berdasarkan Akad wadi'ah atau Akad lain yang tidak bertentangan dengan Prinsip Syariah; dan

2. Investasi berupa Deposito atau Tabungan atau bentuk lainnya yang dipersamakan dengan itu berdasarkan Akad mudharabah atau Akad lain yang tidak bertentangan dengan Prinsip Syariah;

Kemudian dana yang diperoleh tersebut harus disalurkan pada masyarakat dalam bentuk: ${ }^{14}$

1. Pembiayaan bagi hasil berdasarkan Akad mudharabah atau musyarakah;

2. Pembiayaan berdasarkan Akad murabahah, salam, atau istishna';

3. Pembiayaan berdasarkan Akad qardh;

4. Pembiayaan penyewaan barang bergerak atau tidak bergerak kepada Nasabah berdasarkan Akad ijarah atau sewa beli dalam bentuk ijarah muntahiya bittamlik; dan

5. Pengambil alihan utang berdasarkan Akad hawalah;

Menurut Muhammad Akhyar Adnan (1996) dalam Zainuddin ${ }^{15}$ ada beberapa bentuk penghimpunan dana pada Bank Syariah. Bentuk-bentuk penghimpunan dana tersebut dibagi berdasarkan prinsip-prinsip:

1. Wadi'ah

Wadi'ah dalam tradisi Fiqh Islam dikenal dengan prinsip titipan atau simpanan. Namun dapat juga diartikan sebagai titipan murni dari satu pihak ke pihak lain, baik sebagai individu maupun sebagai suatu badan hokum. Titipan dimaksud yang harus dijaga dan dikembalikan kapan saja si penitip menghendaki. Dapat dikatakan sifatsifat wadi'ah sebagai produk perbankan syari'ah berbentuk giro yang merupakan titipan murni (yad damanah).

Dasar hukum wadi'ah adalah firman Allah SWT dalam surah An-nisaa' ayat 58:

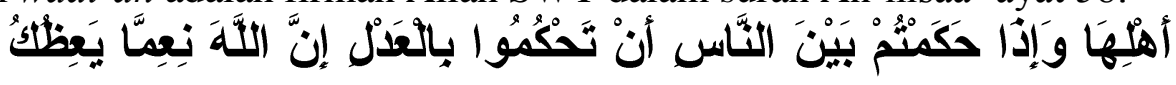

Sesungguhnya Allah menyuruh kamu menyampaikan amant kepada yangberhak menerimanya......"16

2. Mudharabah

Mudharabah berasal dari kata dharb yang artinya memukul. Atau lebih tepatnya adalah proses seseorang memukulkan kakinya dalam perjalanan usaha. Secara teknis mudharabah adalah sebuah akad kerjasama antar pihak, yaitu pihak pertama (shahib al-mal) menyediakan seluruh (100\%) modal, sedangkan pihak lainnya menjadi pengelola.

Dasar hukum mudharabah adalah firman Allah SWT dalam surah al-Muzammil ayat 20: Dan sebagai daripada mereka orang-orang yang berjalan di muka bumi mencari sebagian dari karunia Allah.... ${ }^{17}$

3. Murabahah (pembiayaan dengan margin)

Murabahah merupakan salah satu bentuk menghimpun dana yang dilakukan oleh perbankan syari'ah, baik untuk kegiatan usaha yang bersifat produktif maupun yang bersifat konsumtif. Murabahah adalah jual beli barang pada harga asal dengan

\footnotetext{
${ }^{13}$ Undang-undang Bank Indonesia No.21 tahun 2008 Perbankan Syariah

${ }^{14}$ Ibid

${ }^{15}$ Zainuddin Ali, Prof, Dr, H, M.A, 2007, hal: 23-26,

${ }^{16}$ Lihat surat An-nisaa (4) ayat 58

${ }^{17}$ Lihat surah Al-Muzammil (73) ayat 20
} 
tambahan keuntungan yang disepakati dan tidak terlalu memberatkan calon pembeli.

Secara umum nasabah pada perbankan syari'ah mengajukan permohonan pembelian suatu barang. Dimana barang tersebut akan dilunasi oleh pihak bank syari'ah kepada penjual, sementara nasabah bank syariah melunasi pembiayaan tersebut kepada bank syariahn dengan menambah sejumlah margin kepada pihak bank sesuai dengan kesepakatan yang terdapat pada perjanjian murabahah yang telah disepakati sebelumnya antara nasabah dengan bank syariah.

4. Bai bi As-Saman 'Ajil

Bai bi As-Saman 'Ajil adalah suatu perjanjian yang disepakati antara bank dengan nasabahnya, yaitu pihak bank menyediakan dana untuk pembelian barang/asset yang dibutuhkan oleh nasabah untuk mendukung suatu usaha atau suatu proyek. Selanjutnya nasabah akan membayar secara kredit dengan mark-up yang didasarkan opportunity cot project (OCP).

\section{Musyarakah}

Musyarakah adalah akad kerja sama antara dua pihak atau lebih untuk melakukan suatu usaha tertentu. Masing-masing kontribusi dana (atau amal/expertise) berdaarkan kesepakatan bahwa keuntungan dan resiko akan ditanggung bersama sesuai kesepakatan ketika melakukan akad. Akad jenis ini disebut profit dan loss sharing. ${ }^{18}$

Pada prinsipnya produk penyaluran dana yang dilakukan oleh Bank Syariah dapat digolongkan menjadi empat kategori yaitu: ${ }^{19}$

a. Pembiayaan dengan prinsip jual beli

b. Pembiayaan dengan prinsip sewa

c. Pembiayaan dengan prinsip bagi hasil

d. Pembiayaan dengan prinsip akad pelengkap

Bagi hasil menurut Zainuddin bagi hasil memiliki karateristik :

- Penentuan besarnya rasio / nisbah bagi hasil dibuat waktu akad dengan berpedoman pada kemungkinan untung atau rugi.

- Besarnya rasio bagi hasil berdasarkan pada jumlah keuntungan yang diperoleh.

- Bagi hasil tergantung pada keuntungan proyek yang dijalankan. Apabila usaha merugi kerugian akan ditanggung bersama oleh kedua belah pihak.

- Jumlah pembagian laba bagi hasil dapat meningkat sesuai dengan peningkatan jumlah pendapatan.

- Tidak ada yang meragukan keabsahan bagi hasil.

Pengukuran efisiensi Menurut Muharram dan Purvitasari (2007) dalan Rifki (2010), pengukuran efisiensi dapat dilakukan melalui tiga pendekatan yaitu:

1. Pendekatan rasio

Pendekatan rasio dalam mengukur efisiensi dilakukan dengan cara menghitung perbandingan output dengan input yang digunakan. Pendekatan rasio akan dinilai memiliki efisiensi yang tinggi apabila dapat memproduksi jumlah output yang maksimal dengan input yang seminimal mungkin.

Efisiensi $=$ input/output

${ }^{18}$ Muhammad syafi'ie Antonio, Bank Syariah suatu pengenalan umum, Jakarta : Tazkia

${ }^{19}$ Zainuddin Ali, hal : 31-39 
Chu-Fen $\operatorname{Li}(2007)$ melihat pendekatan rasio sebagai "the most criticallimitation of the financial ratio is that they fail to consider the multiple input-output..." Oleh karena itu pendekatan ini belum mampu menilai kinerja lembaga keuangan secara menyeluruh.

2. Pendekatan regresi

Pendekatan ini dalam mengukur efisiensi menggunakan sebuah model dari tingkat output tertentu sebagai fungsi dari berbagai tingkat input tertentu. Persamaan regresi dapat ditulis sebagai berkut:

$$
\begin{array}{r}
\mathrm{Y}=\mathrm{f}(\mathrm{X} 1, \mathrm{X} 2, \mathrm{X} 3, \mathrm{X} 4 \\
\text { Dimana } \mathrm{Y}=\text { output } \\
\mathrm{X}=\text { input }
\end{array}
$$

Pendekatan ini juga tidak dapat mengatasi kondisi banyak output, karena hanya satu indikator output yang dapat ditampung dalam sebuah persamaan regresi.

3. Pendekatan frontier

Pendekatan frontier dalam mengukur efisiensi dibedakan menjadi dua jenis, yaitu pendekatan frontier parametrik dan non parametrik. Pendekatan parametrik dapat diukur dengan tes statistik parametrik seperti menggunakan Stochastic Frontier Approach (SFA) dan Distribution Free Approach (DFA). Pendekatan frontier non parametrik diukur dengan tes statistik non parametrik yaitu dengan menggunakan metode Data Envelopment Analysis (DEA). Menurut Ghozali dan Castellan (2002), tes parametrik adalah suatu tes yang modelnya mensyaratkan asumsi khusus tentang data. Dalam penelitian ini metode yang digunakan adalah metode non parametrik DEA.

DEA merupakan metodologi non-parametrik yang didasarkan pada linear programming. Pada awalnnya dikembangkan untuk pengukuran kinerja, dan sekarang aplikasi DEA telah dipakai sebagai pengukuran pada berbagai disiplin ilmu pengetahuan dan berbagai kegiatan operasional (Cooper, Seiford dan Tone, 2000). Metodologi ini berhasil diterapkan untuk mengukur kine rja relatif dari sekumpulan perusahaan yang menggunakan beragam input identik untuk menghasilkan beragam output identik. Prinsip-prinsip DEA diperkenalkan oleh Farrel (1957) yang kemudian dikembangkan secara luas oleh Charnes, Cooper dan Rhodes (1978). Metode DEA dibuat sebagai alat bantu untuk evaluasi kinerja suatu aktifitas dalam sebuah unit entitas (organisasi). ${ }^{20}$

Pengukuran efisiensi dengan menggunakan metode DEA dapat dilakukan dengan cara, menentukan variabel-variabel input dan output. Selanjutnya menentukan orientasi model, apakah bertujuan untuk meminimalkan input atau memaksimalkan output. Hubungan variabel input dengan output apakah bersifat Constant return to scale (CRS) atau Variabel return to scale (VRS) merupakan aspek yang penting dalam teknik DEA.

\section{- Formulasi DEA}

Formulasi DEA adalah :

Maksimumkan:

${ }^{20}$ Ventelou dan Bry (2006) Journal of Policy Modeling 28 (2006), hal: 403-413 


$$
\begin{gathered}
Z_{k}=\frac{\sum_{r=1}^{s} U_{r k} \cdot Y_{r k}}{\sum_{i=1}^{m} V_{i k} \cdot X_{i k}} \\
\frac{\sum_{r=1}^{s} U_{r k} \cdot Y_{r k}}{\sum_{i=1}^{m} V_{i k} . X_{i k}} \leq 1 ; j=1, \ldots \ldots \ldots \ldots \ldots, n
\end{gathered}
$$

Dimana : $\mathrm{V}_{\mathrm{rk}} \geq 1 ; \mathrm{r}=1$

$\mathrm{V}_{\mathrm{ik}} \geq 1 ; \mathrm{r}=1$

Program linier fraksional ditransformasikan ke dalam linier biasa dan metode simplek untuk menyelesaikan transformasi tersebut adalah sebagai berikut:

$$
z_{k}=\sum_{r=1}^{s} U_{r k} \cdot Y_{r k}
$$

Dengan kendala:

$$
\begin{aligned}
& \sum_{r=1}^{s} U_{r k} \cdot Y_{r j}-\sum_{i=1}^{m} V_{i k} \cdot X_{i j} \leq 0 ; j=1, \ldots . n \\
& \sum_{i=1}^{m} V_{i k} \cdot X_{i k}=1 \\
& U_{r k} \geq 0 ; r=1, \ldots \ldots . ., s \\
& V_{r k} \geq 0 ; r=1, \ldots \ldots . ., s
\end{aligned}
$$

Dimana :

$\mathrm{Y}_{\mathrm{rk}}=$ jumlah output $\mathrm{r}$ yang dihasilkan BMT $\mathrm{k}$

$\mathrm{X}_{\mathrm{ik}}=$ jumlah input $\mathrm{i}$ yang dihasilkan BMT $\mathrm{k}$

$\mathrm{Y}_{\mathrm{rj}}=$ jumlah output $\mathrm{r}$ yang dihasilkan BMT $\mathrm{k}$

$\mathrm{s}=$ jumlah BMT yang dianalisis

$\mathrm{m}=$ jumlah input yang digunakan

$\mathrm{V}_{\mathrm{ik}}=$ bobot tertimbang dari output $\mathrm{r}$ yang dihasilkan tiap BMT

$\mathrm{Z}_{\mathrm{k}}=$ nilai yang dioptimalkan sebagai indicator efisiensi relative dari BMT

Dalam DEA, efisiensi dinyatakan dalam rasio antara total input dengan total output tertimbang. Dimana setiap unit kegiatan ekonomi diasumsikan bebas menentukan bobot untuk setiap variabel input maupun variable output yang ada, asalkan mampu memenuhi dua kondisi yang disyaratkan yaitu: ${ }^{21}$

1. Bobot tidak boleh negative

2. Bobot harus bersifat universal atau tidak menghasilkan indikator efisiensi yang di atas normal atau lebih besar dari nilai 1, bilamana dipakai unit kegiatan ekonomi yang lainnya.

Angka efisiensi yang diperoleh dengan model DEA memungkinkan untuk mengidentifikasi unit kegiatan ekonomi yang penting diperhatikan dalam kebijakan pengembangan kegiatan ekonomi yang dijalankan secara kurang produktif.

21 Silkman, 1986; Nugroho, 1995; Ari Wibowo, 2004; Lendro Kurniawan, 2005, Rifki Aly Akbar, 2010. Hal: 67 


\section{E. METODE PENELITIAN}

Jenis Dan Sumber Data Penelitian ini merupakan penelitian kuantitatif dengan metode wawancara, survey, dan kuesiner. Sehingga data yang digunakan adalah data primer dan data sekunder dari masing-masing BMT yang dipilih dalam penelitian ini. Tahun data yang dipilih adalah 2010 dengan alas an bahwa pada tahun tersebut diperkirakan BMT telah mengeluarkan dan mempublikasikan hasil laporan keuangan secara lengkap. Sumber data yang digunakan dalam penelitian ini yaitu :

a. Data Primer dalam penelitian ini data primer dikumpulkan dari hasil observasi dan wawancara untuk menggali informasi awal penelitian.

b. Data sekunder, diperoleh dari tangan kedua baik dari objek secara individual (responden) maupun dari suatu badan (instansi) yang dengan sengaja melakukan pengumpulan data dari instansi-instansi atau badan lain untuk keperluan penelitian para pengguna. ${ }^{22}$ Metode dalam penelitian ini yaitu dengan menghimpun informasi dan data melalui studi pustaka dan eksplorasi literatur-literatur dan laporan keuangan yang dibuat oleh BMT yang bersangkutan.

Populasi yang diambil dalam penelitian ini adalah seluruh BMT di Kota Semarang tahun 2010 yaitu berjumlah 72 BMT. Menurut Riduwan populasi adalah objek atau subjek yang berada pada suatu wilayah dan memenuhi syarat-syarat tertentu berkaitan dengan masalah penelitian. ${ }^{23}$

a. Sampel.

Dalam penelitian ini adalah menggunakan Purposive sampling atau sampling pertimbangan, yaitu teknik sampling yang digunakan peneliti jika peneliti memiliki pertimbangan-pertimbangantertentu dalam pengambilan sampelnya atau pengambilan sampel dengan tujuan-tujuan tertentu. ${ }^{24}$ Atau penarikan sampel Purposive adalah penarikan sampel dengan pertimbangan tertentu. Pertimbangan tersebut didasarkan pada kepentingan atau tujuan penelitian. (Suharyadi dan Purwanto, 2004)

Pertimbangan-pertimbangan tersebut yaitu: Jumlah BMT di kota Semarang begitu banyak dan menyebar di seluruh kota, sehubungan dengan keterbatasan waktu dan biaya maka peneliti memilih BMT yang sudah terdaftar dalam Pusat Koperasi Syari'ah Jawa Tengah (PUSKOPSYAH Jawa Tengah), dipilih BMT yang sampai tahun penulisan penelitian masih aktif. Sehingga jumlah BMT nya adalah 12 BMT, yaitu BMT Binama, BMT Hudatama, BMT Walisongo, BMT Damar, BMt Mitra Hasanah, BMT Perkasya, BMt Fosilatama, BMT Attaqwa, BMT Ki Ageng Pandanaran, BMT Bondo Tumoto, BMT Pasadena dan BMT Anda. Sumber : Puskopsyah Jateng, www.microfin semarang.com

Dalam penelitian ini menggunakan Variabel Input yang digunakan dalam penelitian ini adalah total simpanan, beban operasional dan modal dan Variabel Output yang digunakan dalam penelitian ini adalah pembiayaan, pendapatan operasional lain dan rentabilitas.

\section{F. METODE ANALISIS DATA}

Dalam penelitian ini digunakan metode simplek yang diformulasikan dalam bentuk analisis data DEA dengan menggunakan persamaan dari VRS dan CRS. Formulasi CRS dalam penelitian ini adalah :

\footnotetext{
${ }^{22}$ Supangat, 2006, hal : 68, dalam YP Soemitro, 2008.

${ }^{23}$ Riduwan, 2008, hal : 56-57, dalam YP Soemitro, 2008.

${ }^{24}$ Riduwan, 2008, hal : 63
} 


$$
z_{k}=\sum_{r=1}^{s} U_{r k} \cdot Y_{r k}
$$

Dengan kendala:

$$
\begin{aligned}
& \sum_{r=1}^{s} U_{r k} \cdot Y_{r j}-\sum_{i=1}^{m} V_{i k} . X_{i j} \leq 0 ; j=1, \ldots . n \\
& \sum_{i=1}^{m} V_{i k} . X_{i k}=1 \\
& U_{r k} \geq 0 ; r=1, \ldots \ldots . ., s \\
& V_{r k} \geq 0 ; r=1, \ldots \ldots ., s
\end{aligned}
$$

Dimana :

$\mathrm{Y}_{\mathrm{rk}}=$ jumlah output $\mathrm{r}$ yang dihasilkan BMT $\mathrm{k}$

$\mathrm{X}_{\mathrm{ik}}=$ jumlah input $\mathrm{i}$ yang dihasilkan BMT k

$\mathrm{Y}_{\mathrm{rj}}=$ jumlah output $\mathrm{r}$ yang dihasilkan BMT $\mathrm{k}$

$\mathrm{s}=$ jumlah BMT yang dianalisis

$\mathrm{m}=$ jumlah input yang digunakan

$\mathrm{V}_{\mathrm{ik}}=$ bobot tertimbang dari output $\mathrm{r}$ yang dihasilkan tiap BMT

$\mathrm{Z}_{\mathrm{k}}=$ nilai yang dioptimalkan sebagai indicator efisiensi relative dari BMT

\section{G. HASIL DAN PEMBAHASAN \\ PERKEMBANGAN OMZET BMT DI PUSKOPSYAR}

Ke-12 BMT di Semarang yang terdaftar di PUSKOPSYAR tahun 2010 diketahui memiliki omzet yang sangat fantastis semenjak berdiri hingga akhir tahun 2010. Lihat tabel 4.3. Dari tabel dapat disimpulkan bahwa kenaikan tersebut rata-rata hampir $100 \%$ lebih. Ini berarti BMT yang bersangkutan dapat bertahan didera krisis moneter yang terjadi di Indonesia hal ini disebabkan karena cakupan nasabah di BMT adalah kalangan menengah ke bawah yang kebutuhan hidupnya tidaklah terlalu besar. Mereka hanya bertahan untuk hidup bukan untuk mencari kekayaan.

Tabel 2

Peningkatan Omzet Awal Berdiri Hingga Akhir Tahun 2010

\begin{tabular}{|l|l|l|}
\hline Nama BMt & $\begin{array}{l}\text { Omzet awal } \\
\text { berdiri (Rp) }\end{array}$ & $\begin{array}{l}\text { Omzet akhir } \\
2010(\mathrm{Rp})\end{array}$ \\
\hline BMT Binama & $19 \mathrm{M}$ & $45 \mathrm{M}$ \\
\hline BMT Hudatama & 230 juta & $15 \mathrm{M}$ \\
\hline BMT Walisongo & 100 juta & $10 \mathrm{M}$ \\
\hline BMT Damar & 60 jt-an & $3 \mathrm{M}-$ an \\
\hline $\begin{array}{l}\text { BMT Mitra } \\
\text { Hasanah }\end{array}$ & 300 jt-an & $5,061,453,319.00$ \\
\hline BMT Perkasya & $150 \mathrm{jt}-\mathrm{an}$ & $3 \mathrm{M}-\mathrm{an}$ \\
\hline BMT Fosilatama & $100 \mathrm{jt}-\mathrm{an}$ & $10 \mathrm{M}$ \\
\hline BMT Attaqwa & $50 \mathrm{jt}-\mathrm{an}$ & $3 \mathrm{M}$ \\
\hline $\begin{array}{l}\text { BMT Ki Ageng } \\
\text { Pandanaran }\end{array}$ & $327,377,474.00$ & $748,974,124.00$ \\
\hline $\begin{array}{l}\text { BMT Bondo } \\
\text { Tumoto }\end{array}$ & $100 \mathrm{jt}-\mathrm{an}$ & $1 \mathrm{M}-\mathrm{an}$ \\
\hline BMT Pasadena & $50 \mathrm{jt}$ & $450 \mathrm{jt}$ \\
\hline BMT Anda & $50 \mathrm{jt}$ & $2,178,122,233.00$ \\
\hline
\end{tabular}


Sumber : Hasil Wawancara

Omzet tersebut dapat berkembang seterusnya jika pemerintah mendukung kemajuan BMT di Indonesia. Sehingga target-target BMT untuk jangka pendek dan jangka panjang dapat tercapai.

Lulusan pegawai BMT saat ini dari hasil interview disimpulkan bahwa dari 12 BMT tersebut menginginkan pegawai yang lulus dari bangku kuliah Sarjana dan Diploma jurusan Ekonomi manajemen, Akuntansi dan terutama Perbankan Syariah. Diketehui pegawai yang saat ini kebanyakan lulusan dari S1 umum. Hal ini dapat menjadi masukan bagi para calon mahasiswa baru bahwa Lembaga Keuangan Perbankan Syariah membutuhkan para lulusan Perbankan Syariah, baik Diploma maupun S1.

\section{Hasil Analisis Data}

Tabel 3

Tingkat Efisiensi BMT Tahun 2010

\begin{tabular}{|l|c|c|}
\hline \multicolumn{1}{|c|}{ Nama BMT } & Tingkat efisiensi & Ket \\
\hline BMT Binama & $100 \%$ & efisien \\
\hline BMT Hudatama & $29,22 \%$ & Tidak efisien \\
\hline BMT Walisongo & $100 \%$ & efisien \\
\hline BMT Damar & $100 \%$ & Efisien \\
\hline BMT Mitra Hasanah & $61,51 \%$ & Tidak Efisien \\
\hline BMT Perkasya & $100 \%$ & Efisien \\
\hline BMT Fosilatama & $33,28 \%$ & Tidak efisien \\
\hline BMT Attaqwa & $100 \%$ & efisien \\
\hline BMT Ki Ageng Pandanaran & $100 \%$ & Efisien \\
\hline BMT Bondo Tumoto & $47,81 \%$ & Tidak Efisien \\
\hline BMT Pasadena & $62,41 \%$ & Tidak Efisien \\
\hline BMT Anda & $71,18 \%$ & Tidak Efisien \\
\hline
\end{tabular}

Sumber : hasil olah data DEA

Interprestasi hasil data:

1. BMT yang memiliki efisien tinggi (100\%) adalah BMT Binama, BMT Walisongo, BMT Damar, BMT Perkasya, BMT At Taqqwa, BMT Ki Ageng Pandanaran.

2. BMT yang memiliki efisiensi antara $55 \%$ s/d $90 \%$ adalah BMT Mitra Hasanah $(61,51 \%)$, BMT Pasadena $(62,41 \%)$ dan BMT Anda $(71,18 \%)$

3. Sedangkan BMT yang memiliki efisiensi rendah (kurang dari $55 \%$ ) yaitu BMT Hudatama $(29,22 \%)$, BMT Fosilatama $(33,28 \%)$, BMT Bondo Tumoto $(47,81 \%)$

4. Interprestasi BMT yang tidak efisien memiliki ketidak efisiennan rata-rata pada semua input (beban operasional, modal dan simpanan). Lihat lampiran. Ini berarti harus ada pembenahan pengelolaan pada inputnya. Dimana target yang harus tercapai tidak sesuai dengan aktualnya atau nilai targetnya < nilai aktualnya.

5. BMT Hudatama memiliki tingkat efisiensi $29,22 \%$, ketidak efisienan nya terjadi di input beban operasional yang target seharusnya 18,2 \% namun real didapatnya $81,8 \%$ sedangkan modal di dapat 54,8\% lebih besar dari targetnya yaitu 45,2\%.

6. BMT Mitra Hasanah memiliki tingkat efisien $61,51 \%$. Ketidakefisienan terjadi pada input modal nya lebih besar $(74,8 \%)$ dari targetnya yaitu $25,2 \%$. Sedangkan beban dan Simpanan yang dikelolapun lebih kecil dari target yang diharapkan.

7. BMT Fosilatama memiliki tingkat efisien sebesar 33,28\%. Ketidak efisienan seluruh Input $(50,1 \%)$ lebih besar dari target yaitu $49,9 \%$.

8. BMT Bondo tumoto memiliki tingkat efisiensi $47,81 \%$. Ketidakefisiensi terjadi di seluruh input yang lebih kecil dari target yang diharapkan yaitu 64,7 \%. 
9. BMT Pasadena memiliki tingkat efisiensi $62,41 \%$. Ketidakefisiensi pada input yang harus ditingkatkan sebesar 23,1\%,36,9\% dan 23,1\%.

10. BMT Anda tingkat efisiensinya mendekati $100 \%$ yaitu sebesar $71,18 \%$. Input yang harus ditambahkan adalah beban operasional sebesar $62,2 \%$.

\section{H. KESIMPULAN}

Kesimpulan dalam perumusan masalah dalam penelitian ini adalah sebagian BMT di Kota Semarang tahun 2010 memiliki kinerja operasional yang efisien namun sebagian memiliki kinerja operasional yang tidak efisien dan harus diperbaiki di bagian Simpanan, dan beban operasiionalnya supaya tingkat outputnya bisa maksimal. Sedangkan prospek kedepan BMT di Kota Semarang dapat meningkat lebih tinggi mengingat nasabah yang menjadi anggota BMT adalah dari kalangan menengah ke bawah. Hal ini bisa mendukung program pemerintah dimana BMT merengkuh para Usaha Kecil Menengah. Bangkitkan UMKM melalui BMT dapat di respon positif bagi pemerintah. Dapat diidentifikasikan dari ketidakefisiennan yang terjadi akibat pengelolaan input yang kurang maksimal atau pengelolaan output yang kurang minimal. Ketidakefisienan bisa disebabkan beberapa hal, diantaranya:

a. Output melebihi atau kurang dari kapasitas normal. Dilihat dari data pada lampiran dapat disimpulkan bahwa output yang dimiliki dari ke-5 BMT tersebut kurang dari kapasitas normal, sedangkan output yang didapat tidak maksimal. Ini berarti harus ada pengelolaan input kembali.

b. Dari hasil profitabilitas nilai z yang sangat tidak berpengaruh adalah simpanan dengan pembiayaan, sehingga bisa disimpulkan seberapa besar simpanan yang dimiliki BMT tidak mempengaruhi nilai outputnya. Sedangkan modal dan penerimaan beban operasional masing-masing BMT sangat berpengaruh pada outputnya (pembiayaan, pendapatan operasional dan bagi hasil)

c. Karena modal dan beban operasional sangat berpengaruh maka kedua variable inilah yang bisa direkomendasikan untuk merubah pengelolaannya.

\section{Rekomendasi}

Untuk mengatasi terjadinya ketidakesienan dari suatu lembaga maka dapat dibenahi pada:

a. nilai outputnya yang harus ditingkatkan dengan cara mengurangi input,

b. Atau jika kedua output dan input ditingkatkan, maka tingkat kenaikan untuk output harus lebih besar daripada tingkat kenaikan untuk input atau,

c. Jika kedua output dan input diturunkan, laju penurunan untuk output harus lebih rendah daripada tingkat penurunan untuk input.

\section{Kontribusi penelitian}

a. Bagi BMT, hasil peneltian ini dapat membantu cara mengatasi masalah ketidakefisienan yang terjadi di internal BMT yaitu melalui rekomendasi dalam peneltian ini

b. Kelembagaan Akademik,

- penelitian ini dibuat untuk percontohan pengajaran bagi mahasiswa IAIN Walisongo Semarang mengenai penelitian kuantitatif dengan menggunakan program olah data WDEA. Mulai dari cara membuat perumusan masalah, metodologi penelitian, pemilihan sampel, cara pengambilan data dari sampel yang dipilih hingga olah data dan interprestasi hasil data.

- Hasil penelitian ini secara tidak langsung pihak akademik IAIN Walisongo mendapatkan informasi mengenai lulusan-lulusan dari jurusan apa saja yang 
menjadi harapan Lembaga Keuangan Syariah. Harapan para pemilik LKS menerima pegawai yang lulus S1 atau D3 Perbankan Syariah dan Akuntansi. Hal ini bisa menjadi prospek D3 Perbnakan Syariah IAIN Walisongo dirubah menjadi S1 Perbankan Syariah mengingat permintaan Lapangan Kerja di LKS banyak sekali.

\section{Keterbatasan penelitian}

Dalam penelitian ini ada kekurangan yang harus dibenahi yaitu pada data mentah diolah ada 2 BMT yang tidak mengisi angka sesuai realnya namun hanya mengisi jumlah rata-rata yang diterima atau dikelola. Sehingga harapan peneliti ke depannya adalah semua lembaga terkait dengan penelitian terutama dalam penelitian ini adalah BMT yang dijadikan sampel dapat mengisi kuetionare sesuai laporan keuangan demi kemajuan lembaga yang bersangkutan karena disini peneliti secara tidak langsung dapat membantu mencari ketidakefisienan atau kenapa terjadi penurunan kinerja di dalam BMT tersebut sehingga permasalahan dapat teratasi.

\section{SARAN}

Ketidakefisienan yang terjadi di BMT dapat dibenahi mulai dari pengelolaan modal dan beban operasional masing-masing BMT yang tidak efisien. Besarnya modal yang dihimpun dapat dimanfaatkan secara optimal. Semisal :

a. modal yang dihimpun dapat ditujukan untuk memodali UMKM. Dimana UMKM adalah usaha kecil untuk masyarakat menengah yang jumlah pengusahanya sangat besar dan bervariatif. Merekapun pengusaha kecil yang tahan akan gejolak krisis

b. Biasanya BMT belum didukung oleh sarana dan prasarana untuk jasa pelayanan keuangan yang mutakhir maka kegiatan operasional BMT hanya berupa layanan simpanan dan pembiayaan. Keterbatasan layanan BMT tersebut menyebabkan pasarnya tersegmentasi (terbatas), yaitu pada investor yang mengharapkan imbal jasa yang kompetitif sekaligus keamanan dana investasinya. Dari sudut pandang penghimpunan dana maka portofolio sumber dana menjadi kurang optimal. Ironisnya, dengan tipe nasabah yang dimiliki tersebut BMT belum memiliki perlindungan simpanan nasabah (penjaminan resiko bagi nasabah) seperti yang dimiliki Bank Umum. Sementara dari sisi penyaluran dana, pihak BMT juga tidak mempunyai perlindungan asuransi untuk pembiayaan yang diberikan. ${ }^{25}$

${ }^{25}$ Tyas D. Hascaryani Asfi Manzilati Nurman S. Fadjar, Metafora Risk And Return Sebagai Dasar Pengembangan Baitul Maal Wa Tamwil (Bmt) Yang Mandiri Fakultas Ekonomi \& Bisnis Universitas Brawijaya 


\section{DAFTAR PUSTAKA}

Ariyanto, Yudho. 2007. "Efisiensi Perbankan Syariah Di Indonesia Tahun 2005: Aplikasi Metode Data Envelopment Analysis (DEA). Skripsi Tidak Dipublikasikan, FE Undip Semarang

Aziz, Amin. 2004. Pedoman Pendirian BMT. Jakarta: Pinbuk Press.

Aziz, A. dan Rahmadi. 2005. Penilaiaan Kesehatan BMT. Jakarta: Pinbuk Press.

Bastian, Afnan. 2009. "Analisis Perbedaan Asset dan Efisiensi Perbankan Syariah di Indonesia Periode Sebelum dan Sesudah Program Akselerasi Pengembangan Perbankan Syariah 2007-2008 Aplikasi Metode DEA." Skripsi tidak dipublikasikan, Fakultas Ekonomi, Universitas Diponegoro Semarang

Cooper, Willam W., Seiford, Lawrence M., and Tone, Koru., 1999, A Comprehensive Text With Model, Aplication, Reference and DEA-Solver Sofware, Kluwer Academic Publisher, Boston USA

Dewi. 2007. “Analisis Tingkat Kesehatan BMT Dengan Pendekatan CAMEL (Studi pada BMT Binama)." Naskah tidak dipublikasikan, Fakultas Ekonomi, Universitas Diponegoro Semarang

Edy Hartono, "Analisis Efisiensi Biaya Industri Perbankan Indonesia Dengan Menggunakan Metode Parametrik Stochastic Frontier Analysis (Studi Pada Perbankan Yang Terdaftar Di Bursa Efek Indonesia Periode 2004-2007)”, 2009, naskah tidak dipublikasikan.

Ghafur, M. 2007. Potret Perbankan Syariah Indonesia Terkini. Yogyakarta: Biruni Press.

Ghazali, I. dan Castellan, J. 2002. Statistik Non-Parametrik. Semarang: Badan Penerbit Undip.

Hadad, M. D., Wimboh S., Daniel I., Euginea, M. 2003. "Analisis Efisiensi Industri Perbankan Indonesia:Penggunaan Metode Nonparametrik Data Envelopment Analysis (DEA), Bank Indonesia Research Paper, Jakarta

Hadad, Muliaman D, Santoso, Wimboh, Mardanugraha, Eugenia dan Ilyas, Daniel. (2003). Pendekatan Parametrik Untuk Efisiensi Perbankan Indonesia. Universitas Indonesia.

Hadinata, I. dan Manurung, A. H. 2007. Penerapan Data Envelopment Analysis (DEA) untuk mengukur Efisiensi Kinerja Reksa Dana Saham. http//www.google.com. Diakses tanggal 26 Desember 2009.

Huri, M. D dan Susilowati, I. 2004. "Pengukuran Efisiensi Relatif Emiten Perbankan Dengan Metode Data Envelopment Analysis (DEA): (Studi Kasus: Bank-Bank yang Terdaftar di Bursa Efek Jakarta Tahun 2002 )." Dinamika Pembangunan. Vol. 1, No.2 Desember, hal. 95-110

Kurnia, A. S. 2004. "Mengukur Efisiensi Intermediasi Sebelas Bank Terbesar Indonesia Dengan Pendekatan Data Envelopment Analysis (DEA).” Jurnal Bisnis Strategi, Vol.13, Desember 2004

Kurniawan, Leandro. 2005. "Analisis Efisiensi Sektor Unggulan di Kab.Banyumas periode 1988-2003. Aplikasi Metode DEA” Skripsi tidak dipublikasikan, Fakultas Ekonomi, Universitas Diponegoro Semarang

Mu'alim, A. dan Abidin, Z.2005."Profesionalisme Praktisi BMT di Kota Yogyakarta dan Kabupaten Sleman." Millah, Vol.IV, No.2, http://www.google.com. Diakses tanggal 27 Desember 2009. 
Muhammad Kholim, 2004, Eksistensi Baitul Maal Wattamil Dan Permasalahannya Dalam Operasionalisasinya (Studi Di Propinsi Jawa Tengah), Skripsi tidak dipublikasikan, Fakultas Ekonomi, Universitas Diponegoro Semarang

Muharam, H dan Purvitasari, R, 2007. "Analisis Perbandingan Efisiensi Bank Syariah dengan Metode Data Envelopment Analysis (periode tahun 2005), Jurnal Ekonomi dan Bisnis Islam, Vol.2, No.3

Purwantoro, N. 2005. Penerapan DEA sebagai Model Alternatif Untuk Menilai Produktifitas Lembaga Pembiayaan Mikro, Jurnal Manajemen Usahawan Indonesia, No.01, XXXIV Januari 2005

Ridwan, M. 2004. Manajemen Baitul Maal Wa Tamwill. Yogyakarta: UII press.

Rifki Ali Akbar, 2010, Analisis Efisiensi Baitul Mal Wa Tamwil Dengan Menggunakan Data Envelopment Analysis (Dea) (Studi Pada Bmt Bina Ummat Sejahtera Di Jawa Tengah Pada tahun 2009), naskah tidak dipublikasikan.

Sadrah, E. Suhendi, H., Juhaya.S.P, Habib.N.A, Ahmad.H. R., Ending.S., Yadi.J., Deni.K.Y. 2004. BMT dan Bank Islam.Bandung: Pustaka Bani Quraisy

Santoso, B. S. 2003. Analisis Tingkat Kesehatan BMT Ditinjau dari Aspek Manajemen, Jurnal Akuntansi-Bisnis \& Manajemen, Vol.10(2), 144-158 Oktober 2003

Tyas D. Hascaryani Asfi Manzilati Nurman S. Fadjar, Metafora Risk And Return Sebagai Dasar Pengembangan Baitul Maal Wa Tamwil (Bmt) Yang Mandiri Fakultas Ekonomi \& Bisnis Universitas Brawijaya

www.bi.go.id

www.pinbukpress.com

Vicky, dkk, 2008, Pengukuran Kinerja Bank Komersial Dengan Pendekatan Go-Publik Di Indonesia, Jurnal JAAI Volume 12 No.1 Juni 2010

Zainuddin Ali, 2007, Hukum Perbankan Syariah, Sinar Grafika, Jakarta. 